\title{
CONFESSION IN ANCIENT EGYPT
}

\author{
JAN ASSMANN
}

There is much to be said about "Ritual and Ethics" in Ancient Egypt, but there is hardly anything that could count as a "pattern of repentance". The concept and phenomenology of repentance seem to be alien to ancient Egyptian culture. What comes closest to what we are looking for are "patterns of confession" - and I propose to have a closer look at two of them, which differ from each other in a very fundamental way: the confessions of workmen of Deir el Medina inscribed on ex-voto stelae during the Ramesside era (13th and 12th cent. B.C.E.) and the "negative confession" or "declaration of innocence" the deceased is supposed to recite before a divine tribunal before entering the other world.

\section{Confession in the Context of Illness and Healing (Guilt as Separation and Concealment)}

During the 13th cent. B.C.E., a most dramatic change occurred in Egyptian religion and mentality ${ }^{1}$. Until then, misfortunes were attributed to demons, evil spirits, enemies and their magic, and magic was considered to be a weapon, given to mankind by the creator himself in order to ward off these undesirable influences ${ }^{2}$. On the other hand, there existed also a notion of a connection between doing and faring, that is, the idea that good actions would be rewarded by happiness and success, and that bad actions would lead to ruin and misfortune. There is even an Egyptian expression for this idea occurring in the very same text that calls magic a weapon to ward off evil. In the Instruction for Merikare the teacher says: "A blow is repaid by its like: this is the dovetailing of all actions"3. This kind of connectivity, however, seems to refer not to divine punishment, but, rather, to a kind of immanent providence which the Egyptians call "Ma'at". Ma'at is what one could call "iustitia connectiva" ${ }^{4}$ : the principle that links actions with consequences.

${ }^{1}$ For this development see my book Ägypten - eine Sinngeschichte (München: 1996) pp. 259-277.

${ }^{2}$ On the Instruction for Merikare, see M. Lichtheim, Ancient Egyptian Literature, vol. I (Berkeley: 1973) p. 106.

${ }^{3}$ Ibid., p. 105.

${ }^{4}$ See my book Ma'at - Gerechtigkeit und Unsterblichkeit im alten Ägypten, 2nd ed. (München: 1995). 
Misfortune, therefore, could be attributed either to the evil influence of some demonic agency such as a curse, or to the consequences of one's own evil actions or bad character.

During the New Kingdom, however, a new interpretation gained more and more acceptance. According to it, misfortune, especially certain forms of illness, might be seen as punishment by an offended deity ${ }^{5}$. In these cases, magic was not considered to be a proper remedy. Rather, steps were taken in order to reconcile the offended deity. Some texts, all of them coming from the workmen's village in Deir el Medina, give us some information about the procedure. In one of these inscriptions we read:

"I will make this stela in your name

And establish for you this hymn in writing upon it.

For you saved me the draughtsman Nakhtamun".

Thus said I and you did hearken to me.

Now mark, I do what I have said ${ }^{6}$.

Here, a certain Nebre, who had this stela erected on behalf of his son Nakhtamun, quotes the vow that he made in a situation of distress. Then, after a turn for the better, he erected the stela in fulfilment of the vow. If we may extrapolate from this and other examples, we arrive at something like the following order of events:

1. The first event is the experience of a crisis, in this case a serious illness of Nakhtamun.

2. The second event consists in publicly praying to the offended god, in our case Amun, and in making a vow to erect a stela in case of salvation.

He made hymns to his name

because of the greatness of his power.

He made humble entreaties before him,

in the presence of the whole land

for the draughtsman Nakhtamun, justified,

who lay sick unto death,

who was under the might of Amun because of that cow?

Here, we encounter two motifs that are of prime importance in the context of confession: the motif of public humiliation ("in the presence of the whole land") and the motif of guilt.

5 See F.J. Borghouts, "Divine Intervention in Ancient Egypt and its Manifestation", in Gleanings from Deir el-Medina, eds. R.J. Demarée and J.J. Janssen (Leiden: 1982) pp. 170 .

${ }^{6}$ See Ägyptische Hymnen und Gebete (= ÄHG), ed. J. Assmann (Zürich: 1975) No. 148

B 57-62; M. Lichtheim, Ancient Egyptian Literature, II (Berkeley: 1977) p. 107.

7 ÄHG, No. 147 B 32-38; Lichtheim, Ancient Egyptian Literature, p. 106. 
3. The third event consists in the experience of salvation.

I found that the lord of Gods came as the north-wind, sweet airs before him,

that he might save the draughtsman of Amun,

Nakhtamun, justified, son of the draughtsman of Amun in the place of truth Nebre, justified, and born of the lady Pashed, justified.

He said:

Though the servant was disposed to do evil,

Yet is the lord disposed to be merciful.

The lord of Thebes passes not a whole day in anger.

His wrath is finished in a moment and nought is left.

The wind is turned to us in mercy,

Amun turns with his air.

As thy Ka endures, mayst thou be merciful!

We shall not repeat our misdeed ${ }^{8}$.

4. The fourth and last event is the erection of the stela.

Sometimes, these stelae were erected in times of distress and contain prayers for forgiveness and a promise to tell the power of the god or goddess to the whole world. These texts are commonly classified as penitential hymns (Bußlieder). In most cases, however, a stela was erected like in our example after an experience of healing and salvation. These texts are called hymns of thanksgiving (Danklieder). There are many parallels for both forms in the Biblical book of Psalms ${ }^{9}$.

What is most characteristic of these confessions is a certain pathos of public announcement, an intention of making known to the whole world a private experience of a rather shameful kind. This is how the hymn inscribed on Nebre's stela starts:

I will make him hymns in his name,

I will give him praise up to the height of heaven

And over the breadth of the earth.

I will declare his might to him who fares down-stream

And to him who fares up-stream.

Be ye ware of him!

Herald him to son and daughter,

To the great and the little.

Declare ye him to generations and generations,

To those that exist not yet.

Declare him to the fishes in the stream,

8 ÄHG Nr. 147, B 46-54; Lichtheim, Ancient Egyptian Literature, pp. 106-107.

9 See F. Crüsemann, Studien zur Formgeschichte von Hymnus und Danklied in Israel ("WMANT", 32; Neukirchen: 1968). 
To the birds in the heaven.

Herald him to him that knows him not and him that knows him.

Be ye ware of Him!

Let us have a look at some other texts of this genre. The stela of a certain Nefer'abu dedicated to a Theban goddess starts right away with the confession:

I was an ignorant man and foolish,

Who did not know good from evil.

I wrought the transgression against the peak

And she chastised me.

I was in her hand by night as by day,

I sat like the woman in travail upon the bearing-stool

I called upon the wind and it did not come to me.

I was libating to the Peak of the West, the mighty one,

And to every god and every goddess (saying:)

Mark, I shall say to great and little

That are among the workmen:

Be ye ware of the Peak!

For that a lion is within the Peak.

She smites with the smiting of a savage lion.

She pursues him who transgresses against her.

I called upon my mistress;

I found that she came to me with sweet airs.

She was merciful to me,

After she made me see her hand.

She turned again to me in mercy,

She caused me to forget the sickness that had been upon me.

Lo, the Peak of the west is merciful

If one calls upon her.

Mark, and let every ear hearken

That lives upon earth:

Beware the peak of the west! ${ }^{10}$

Again we meet with some typical motifs. There is the motif of confession and the pathos of public annunciation. The text proclaims the power of the goddess both in its punishing and in its saving and forgiving aspects. The experience of salvation is again introduced by the words "I found" which occur again and again in similar contexts.

The same Nefer'abu erected a stela to Ptah in which he mentions the particular sin committed by him in the confession. The inscription starts with a title like a literary work.

Beginning of the declaration of the might of Ptah [...]

by $[\ldots]$ Nefer'abu, justified; he says:

10 ÄHG No. 149; Lichtheim, Ancient Egyptian Literature, pp. 107-109. 
I am a man who swore falsely by Ptah, Lord of Truth,

And he caused me to see darkness by day.

I will declare his might to him that knows him not and to him that knows him,

To little and great.

Be ye ware of Ptah, Lord of Truth!

Lo, he will not leave aside any deed of any man.

Refrain from uttering the name of Ptah falsely.

Lo he that utters it falsely,

Lo he tumbles down.

He caused me to be as the dogs of the street,

I being in his hand.

He caused men and Gods to mark me,

I being as a man that has wrought abomination against his lord.

Righteous was Ptah, Lord of Truth, against me when he chastised me.

Be merciful to me; look upon me that you mayest be merciful ${ }^{11}$.

The motif of annunciation and publication is here very prominent. I think that it is precisely this intention which finds its terminological expression in the title "declaration of power". This even seems to be the designation of the genre. The term occurs frequently in this context. Especially the vow to proclaim the power of the deity to everybody is couched in the formula "I will proclaim your power to the fishes in the river and to the birds in the heaven"12, "I will proclaim his power to him who sails upstream and to him who sails downstream"13; "I will proclaim your power to him who knows you not and to him who knows you" ${ }^{4}$, etc. As far as the motif of publicity is concerned, the idea of proclaiming god's power to fishes and birds seems particularly interesting. Brunner has devoted a little study to this motif ${ }^{15}$. He compares it to Christian ideas of preaching to the animals. But it is obvious that we are dealing here with figurative speech. Birds and fishes symbolize cosmic realms and the idea of an all-encompassing publicity. The whole world is to be told the power of god. The basic idea seems to be that an act of divine intervention in the private affairs of an individual requires public proclamation. If such an event occurs it has to be told to everybody. The manifestation of divine power is regarded as a miracle and has to be proclaimed. The Greek term for this literary form and function is "aretalogia", the telling of the "arete" of god, his power, righteousness and efficacy. In the Greek world, especially in Asia Minor but also in all other places of the Hellenistic

11 ÄHG No. 150; Lichtheim, Ancient Egyptian Literature, pp. 109-110.

12 Alan Rowe, "Stela of Huy, Viceroy of Nubia under Tut-Ankh-Amen", ASAE, 40 (1940) p. 47ff; W. Helck, Urkunden der 18. Dynastie (Heft 22 = Urk IV; Berlin: 1958) 2075; Turin 284.

13 Berlin $20377=$ ÄHG No. 148.

14 Bankes 7 = ÄHG No. 161.

15 H. Brunner, "Verkündigung an Tiere", in Fragen an die altägyptische Literatur, ed. E. Otto (Wiesbaden: 1977) pp. 119-124. 
and Roman worlds we find precisely the same institution. Stelae are erected in order to make publicly known the guilt, punishment and salvation of an individual sinner. The idea of publicity and publication seems to be inseparably linked to the concept and institution of confession. Two reflections may help to better understand this link between confession and publication.

Firstly, the manifestation of divine power has to be regarded as a kind of revelation. In Egypt, the deities are remote and hidden. They are represented on earth in the form of images. Especially the Ramesside texts insist on the hiddenness of $\mathrm{God}^{16}$. The more hidden the gods, the more miraculous and spectacular are their unexpected manifestations. They have an appellative character; there is an obligation to make them known and to spread the message. Secondly, there is a sharp contrast between the privacy of sin and the publicity of confession. By its very publicity, the act of confessing is able to annihilate the sin and guilt of the person. Guilt has an isolating effect. By committing a crime, a person separates him/herself from decent society. The evildoer forgoes the benefits of common confidence and communication and excludes himself from the realm of mutual understanding. By making himself opaque or intransparent to his fellows, he shuts himself up in the privacy of his guilt. This act of culpable self-isolation can only be repaired by an opposite act of public self-thematization or "self-publication". This turn from separation to integration can only be done in public; it necessarily requires visibility and publicity. What is not required here is an internal process of turning, of repentance or "contrition".

This is not to say that the ancient Egyptians were not interested in inner life, psychical events and mental attitudes. On the contrary, there are many contexts in which it is the heart that counts ${ }^{17}$. But in the context of these confessions, the heart is rarely ever mentioned.

In the aforementioned cases, the form of confession occurs within a procedure of healing. Confession is part of a therapy. If the connection between guilt and illness has been established, the only way of healing the illness is getting rid of the guilt. This can only be done by asking the offended deity for forgiveness and reconciliation, and the proper way of receiving forgiveness is confession. Suffering is interpreted as a kind of crisis to be overcome by confession, because the cause of the crisis had been separation and

${ }^{16}$ See my book Egyptian Solar Religion in the New Kingdom. Re, Amun and the Crisis of Polytheism (London: 1995) pp. 133-155.

17 See H. Brunner, "Das Herz im ägyptischen Glauben", in Das Herz im Umkreis des Glaubens, I (Biberach: Dr. Karl Thomae GmbH, 1965) pp. 81-106, repr. in Das Hörende Herz. Kleine Schriften zur Religions- und Geistesgeschichte Agyptens, ed. H. Brunner ("OBO", 80; Fribourg: 1988) pp. 8-44; J. Assmann, "Zur Geschichte des Herzens im alten Ägypten”, in Die Erfindung des inneren Menschen, eds. J. Assmann and Th. Sundermeier (Gütersloh: 1993) pp. 81-112. 
concealment. Confession re-establishes the link that had been broken by the evil action and which is a link connecting an individual with society and with a god. As long as the evil action remains the secret of the evildoer, the separation grows. But the growing gap between the individual, society, and the deity can be bridged by breaking the concealment and by making the deed public. Speech and language serve as means of re-socialization.

\section{Confession in the Context of Death and Immortality (Guilt as Pollu- tion, Confession as Purification)}

In the second part of this article, I would like to compare these confessions to an apparently rather different kind of confession which is a much more common and widespread conception in ancient Egypt: the so-called "negative confession" which the deceased is supposed to make during the judgement of the dead. At first sight, the difference between these two forms of confession could not be greater. We shall see, however, that there are also common features. Before making the comparison, let me briefly describe the confession before the judges of the dead.

According to the classical conception, which dates back at least to the 15 th century B.C.E. and persists until Late Antiquity, every Egyptian individual was believed to be summoned after death to a divine tribunal in order to confront possible accusations, to be purged of his/her sins and to be "justified" against his/her enemies ${ }^{18}$. The central scene or "icon" representing this idea of purification and justification is the "psychostasia" or weighing of the heart, showing a balance with two scales, one containing the heart of the deceased, the other a figure of Ma'at, that is, truth-justice-order. The figure of Ma'at symbolizes a complex of norms. Guilt is defined as a violation of one of these norms. A complex of norms functions both ways: it helps to prevent evildoing, but it also generates guilt. This cyclical structure has been described and possibly discovered by Saint Paul and may thus be called the Pauline cycle. According to Paul, the Law that has been given to man in order to show him a guiltless way of life at the same time acts as a generator of guilt. Without a norm to be violated, there would not be any guilt. The Egyptian terminology points to a similar idea. A common denomination of the judgement after death is "calculating the difference". It refers to the difference between the norms of Ma'at and an individual life.

The heart, which is so conspicuously absent in our first paradigm of confession, plays a central role in this second paradigm. It symbolizes the "inner

18 On the Egyptian idea of the dead judgement, its historical development and its influence on other cultures, see J.G. Griffiths, The Divine Verdict. A Study of Divine Judgment in Ancient Religions (Leiden: 1991). 
self" of the deceased, that is, his memory or conscience where the sins he committed during his lifetime are stored. The test of the balance is to ascertain the state of the heart: whether it is full of accumulated guilt which would mean that it is heavy, or whether it is full of Ma'at which would mean that it is light like a feather.

The notion of accumulation and, thus, of time is central to the concept of guilt. Before continuing my description of the judgement after death I would like to insert here a short excursus on guilt and time. Ruth Benedict, in her book The Chrysanthemum and the Sword, introduced the distinction between shame cultures such as Japan and guilt cultures such as Christianity ${ }^{19}$. Eric Dodds elaborated on this distinction in applying it to Homeric and Classical Greece ${ }^{20}$. The distinction between shame and guilt is very pertinent to our context. Shame is related to perception, to seeing and being seen. The notion of guilt, on the other hand, is related to memory, to remembering and being remembered. In a shame-culture, a transgression that passes unnoticed vanishes and does not constitute a problem. In a guilt-culture, however, even unnoticed transgressions stay on in the memory of the wrongdoer, form part of his person and constitute a problem that needs to be handled.

The Egyptians made the distinction between face and heart. "In the face" means an outward appearance of something; "on the heart" means an inward opinion or evaluation of something. The difference between these two expressions refers to the difference between a space of intervision and a space of interlocution. In the space of intervision, people are striving to form and sustain a face to show to each other and the most important concern is not to lose this face. In the space of interlocution people are striving not to show but to express themselves, to speak and listen to each other, and they form organs of expression and understanding. The greatest concern here is to remember and to be remembered. In Egyptian anthropology, the heart is the seat of understanding and memory. The sphere of shame is horizontally structured by social control and mutual perception, and the sphere of guilt is vertically structured by reference to the past. The horizontal structure of shame - the space of intervision - is dominated by synchrony, the vertical structure of guilt, the space of interlocution, is dominated by diachrony. The face is directed towards the present and towards synchrony, but the heart is the organ extending into past and future. Guilt is closely related to expectation and memory.

This relationship between guilt and diachrony can be illustrated with reference both to Nietzsche and to Egyptian texts. Nietzsche, in his book on the Genealogy of Morals, demonstrated the artificiality of social memory,

${ }^{19}$ R. Benedict, The Chrysanthemum and the Sword. Patterns of Japanese Culture (New York: 1974) p. 222ff.

${ }^{20}$ E.R. Dodds, The Greeks and the Irrational (Berkeley: 1966). 
what he calls the memory of the will and what he believes to be not only a human phenomenon but also a human invention, an acquisition in the process of civilization. This kind of memory is the exclusive property of man who is "the animal that is allowed to make promises". "Precisely this necessarily forgetful animal - Nietzsche writes - in which forgetting is a power, a form of strong health, has cultivated within himself a counter-capability, a memory, that enables him in certain cases to suspend ("unhinge") forgetting, viz. in those cases where a promise is to be made: it is therefore not only a passive not-being-able-to-get-rid of the engraved impression [...] but with an active not-being-willing-to-let-loose, a permanent willing of what had once been willed, a veritable memory of the will" ${ }^{21}$. Man, in order to live in civil society, has to cultivate a memory allowing him to make and to keep promises, to enter into obligations and to become calculable. This is precisely the diachronic space of interlocution, which can only be inhabited by those who possess this memory and diachronic identity (= being tomorrow the same as today and yesterday). A number of Egyptian texts point in precisely the same direction. In a text from about 2000 we read: "a sluggard has no yesterday" 22 , i.e. no past, no memory, no conscience, no responsibility. The opposite, the ideal, is the responsible person who is able to remember: "A good character returns to his place of yesterday, for it is said: Do to the doer to make him do. It is thanking a man for what he does" 23 . If the past is forgotten, people no longer do anything to each other, do no longer repay good with good and evil with evil. In those times, the world will be "out of joint". This is a common complaint in Egyptian literature. Thus we read in another important text of the same period: "To whom shall I speak today? The past is not remembered. Nobody does for the doer nowadays" 24 . If the past is not remembered, the social coherence disintegrates and the world turns into an arena of general fighting, a bellum omnium contra omnes. "Lo people fight in the arena, for the past is forgotten. Success eludes him who no longer knows him whom he has known" 25 .

21 "Eben dieses notwendig vergeßliche Tier, an dem das Vergessen eine Kraft, eine Form der starken Gesundheit darstellt, hat sich nun ein Gegenvermögen angezüchtet, ein Gedächtnis, mit Hilfe dessen für gewisse Fälle die Vergeßlichkeit ausgehängt wird - für die Fälle nämlich, daß versprochen werden soll: somit keineswegs bloß als ein passivisches Nicht-wieder-los-werdenkönnen des einmal eingeritzten Eindrucks [...] sondern ein aktives Nicht-wieder-los-werdenwollen, ein fort-und-fort-wollen des einmal Gewollten, ein eigentliches Gedächtnis des Willens":

F. Nietzsche, Werke in drei Bänden, ed. K. Schlechta, II (München: 1960) pp. 799-800.

${ }^{22}$ Eloquent Peasant B 2:109-10; Assmann, Ma'at, p. 60.

${ }^{23}$ Eloquent Peasant B 1:109-110; F. Vogelsang, Kommentar zu den Klagen des Bauern (“Unters. z. Gesch. u. Altertumsk. Äg.”, 6; Leipzig: 1913) p. 100.

${ }^{24}$ Berlin 3024, 115-16, ed. A. Erman, Das Gespräch eines Lebensmüden mit seiner Seele (Berlin: 1896). Many recent translations, i.a. by Erik Hornung, Gesänge vom Nil (Zürich: 1990) p. 115.

${ }^{25}$ Instruction of king Amenemhet I, Millingen 10-11; Section V d-e, ed. Wolfgang Helck, Die Lehre des Amenemhet (Wiesbaden: 1969) pp. 35-37. Cf. W. Westendorf, "Die Menschen 
Guilt can thus be defined as forgetfulness of one's obligations. Nietzsche's basic example is debt, the obligation to pay back one's debts and to keep one's promises. This relates to the future. The Egyptian example is gratitude, the obligation to remember and to answer received benefits. This relates to the past. The greatest sin, for the Egyptians, is greed or avarice. Greed destroys the diachronic space of interlocution and confines a person in the cage of the present moment. Greed destroys this kind of connectivity, which connects a human being to its fellows and which connects the present moment to the past and the future. The Egyptian expression for this connectivity is "Ma'at". "Ma'at", in Egyptian thought, is not just an art of living, but an art of living-together.

"Ma'at" is the principle of social and temporal connectivity. It keeps time and society together. He who lives according to $\mathrm{Ma}$ 'at remembers and will be remembered. Ma'at is not only a body of prescriptions and norms, but also a promise of duration and immortality. Violating Ma'at, therefore, does not only mean to transgress a norm and to need punishment, but to lose a reward, to break a basic contract promising immortality to those who stay within Ma'at. Ma'at promises permanence in time, which is conceived of as a memory-space. A virtuous life bestows permanence to a person so that he/she may live on in this memory-space of permanence. Guilt, however, prevents a person from entering into this space, which is conceived as a strictly pure and guilt-free sphere where only the guiltless are given access.

Unlike shame, guilt accumulates. This is due to the specific relation between guilt and time. Every guilt-culture is, therefore, confronted with the problem of how to dispose of accumulated guilt and to develop techniques of guilt-disposal such as purification, confession, repentance, penitence etc. If these cultural techniques or institutions succeed in purging accumulated guilt on a regular base, we may speak of purification cultures. If, however, guilt is accumulated in spite of or beyond these cultural efforts of purification, we are dealing with real or emphatic guilt cultures. Judaism and Christianity belong to the second type, ancient Egypt to the first one. In ancient Egypt, guilt never accumulates in such a way as to constitute a severe cultural problem and a semantic resource. Unlike the Israelites and the Greek tragic poets, the Egyptians were never able to make much sense of guilt and to convert guilt into a meaningful phenomenon. Egypt clearly belongs to the category of guilt-culture and not of shame-culture. But within the category of guilt-cultures, Egypt belongs to the sub-category of purification cultures as opposed to "emphatic guilt cultures" for which guilt is a resource of cultural meaning. 
The Egyptian idea of a judgement of the dead can be interpreted as a purification ritual. In its earliest form, this idea is cast into the form of a ritual that forms part of the mummification procedure and is thus closely related to ideas of purification and conservation. We are again in a context of crisis and healing. This time, the crisis is not illness but death. For the Egyptians, however, this does not mean the end. There is much to be done about death and dying. It is not the end but another kind of crisis, which can be overcome by purification. The mummification ritual concerns the body; the justification ritual concerns the soul.

In the present context, the most interesting feature is the fact that the justification ritual implies a kind of confession as well as the healing ritual we have dealt with in the first part. During the process of the weighing of the heart against the feather as the symbol of Ma'at, the deceased is supposed to recite a long declaration of innocence or "negative confession" 26 . The confession, which the deceased is supposed to recite before the tribunal, is given in negative form. The deceased mentions some eighty-two sins and declares not to have done them. This is the contrary of what "confession" normally means. The question is, however, to what degree the norms mentioned in the "confession" had any importance for the life style of the person. My thesis is that this is the whole point of the classical model. The ancient or mythical model did not provide any clues as to the conduct of a living person. You had to be prepared for any confrontations and any accusations. The classical model is a decisive step in the direction of rationalization. Now you knew against which accusations you had to defend yourself. The classical model thus provides a very close relationship between ritual and ethics. The ritual of the judgement of the dead now assumes a form in which it was able to influence the lifestyle of the living. In this list, specific norms are spelled out, norms that a person has to obey in order to qualify for the other world. Thus, one is capable of preparing oneself during lifetime for the judgement, by avoiding violating these norms. There is no doubt that the ritual must be interpreted as a magic support, helping the individual to pass the test of the balance. However, this does not mean that it served as a substitute for moral conduct. Magic and morals did not exclude each other in ancient Egypt but worked together in the same way as magic and medicine worked together in medical practice. In ancient Egypt, every physician practised magic along with his purely medical applications. He would never have thought of magic as a substitute for what we would call a proper medical treatment but would always use magic as a complementary way reinforcing his medical treatment. In the same way we must conceive of magic and morals working together in the purification ritual of

${ }^{26}$ Charles Maystre, Les déclarations d'innocence (Kairo: 1937). 
the deceased. Any guilt caused by violating one or more of the so-called "laws of the hall of judgement" may be "purged" just by verbal negation: "I did not do it". But this does not mean that a person may not try to avoid committing these particular sins as prohibited by the laws of the hall of judgement during his/her lifetime ${ }^{27}$.

One of the most conspicuous traits of the negative confession is its public character. This is also the feature that is common to both paradigms of confession. The deceased is supposed to make this confession before the whole land, represented by the 42 judges. 42 is the number of the nomes. Each one of the judges is assigned a specific town and nome. Their totality symbolizes the totality of the land which means, the world. Again, we meet with the idea that confession means publication. It seems to me obvious that the guilt, which the deceased wants to be purged of in the purification ritual of the judgement after death, consists mainly in secret sins beyond reach of secular justice. Many, if not most of the sins, which the deceased is to abrogate in the negative confession, concern moral prescriptions without any legal implications. You could not litigate a person for crimes such as making people cry, making too many words, raising your voice, speaking inconsiderately, winking to somebody, being arrogant, hot-headed, irascible, violent, being deaf against words of truth, etc.

The sins to be confessed both in the judgement of the dead and in the context of Personal Piety concern crimes and misconduct that lay beyond the reach of legal institutions. Radical Enlightenment has made the point that no civil society could ever be based on legal institutions alone and that religion is a necessary and inevitable invention in order to prevent people from violating each other ${ }^{28}$. We meet with this argument as early as the 5th cent. B.C. $\mathrm{E}^{29}$. Reductionist as this argument is, we should not close our eyes before the fact that sin is a most forceful instrument of dominion and that the Egyptian idea of a judgement of the dead arises in the context of the state of the Middle Kingdom and its forceful political theology. The concept of Ma' at has unmistakably political implications. However, the same does not necessarily apply for the concept of Personal Piety, which views individual life as subject to divine intervention and the individual person therefore responsible for his/her ways of life, not only at the end but constantly during lifetime. This view of a god-man relationship implies concepts of divine presence that transcend the sphere of the social and the political and establish a specifically religious form of personal commitment and responsibility.

${ }^{27}$ See M. Lichtheim, Ma'at in Egyptian Autobiographies and Related Studies ("OBO", 120; Fribourg: 1992).

${ }^{28}$ Margaret C. Jacobs, The Radical Enlightenment. Pantheists, Freemasons and Republicans (London: 1981).

${ }^{29}$ Critias fr. 43 F 19 Snell. 